\title{
Karakteristik Fisikokimia dan Aktifitas Antioksidan Daging Itik yang Dilapisi Ekstrak Propolis Selama Penyimpanan Suhu Ruang
}

\author{
Physicochemical Characteristics and Antioxidant Activity of Duck Meat Coated with Propolis Extract \\ During Room Temperature Storage \\ A. Apriantini", S. Adinata, \& Y. C. Endrawati \\ Departemen Ilmu Produksi dan Teknologi Peternakan, Fakultas Peternakan, Institut Pertanian Bogor \\ Jl. Lingkar Akademik, Kampus IPB Darmaga, 16680, Bogor, Indonesia \\ *Corresponding author: astariapriantini@yahoo.com \\ (Received 26-07-2021; Revised 12-08-2021; Accepted 20-09-2021)
}

\begin{abstract}
Duck meat is a perishable food that has a short shelf-life. Therefore, packaging is needed to be used to maintain duck meat quality during storage, one of the ways to extend shelf-life of duck meat is using propolis extract as edible coating which is contained antioxidant substances which can be used to extend during storage. The aim of this research was to analyze the effect of propolis extract as an edible coating material on duck meat to maintain the quality and extend shelf-life of duck meat at room temperature. The research was used a completely randomized design (CRD) factorial 4x3 with 3 replications, consisting of 4 propolis concentrations $(0.0 \%, 0.5 \%, 1.0 \%, 1.5 \%)$ and 3 storage times $(0$ hours, 6 hours and 24 hours). Duck meats coated with propolis extracts had a significant effect on the water content and antioxidant activity of duck meat $(\mathrm{P}<0.05)$. The storage time had a significant effect on the pH value and the cooking loss of duck meat $(\mathrm{P}<\mathbf{0 . 0 5})$. The addition of propolis extract and storage time had a significant effect on the $\mathrm{pH}$ value, cooking loss and antioxidant activity of duck meat $(\mathrm{P}<0.05)$.
\end{abstract}

Keywords: Duck meat, edible coating, propolis

\section{ABSTRAK}

Daging itik merupakan produk pangan hewani yang mudah rusak dan memiliki umur simpan yang pendek. Oleh karena itu diperlukan pengemasan yang dapat digunakan untuk mempertahankan kualitas daging itik selama masa penyimpanan dan aman dikonsumsi, salah satunya adalah dengan menggunakan edible coating dari ekstrak propolis. Penelitian ini bertujuan untuk menganalisis pengaruh penggunaan ekstrak propolis sebagai bahan edible coating pada daging itik untuk mempertahankan mutu daging itik pada penyimpanan suhu ruang. Rancangan penelitian ini menggunakan Rancangan Acak Lengkap (RAL) pola faktorial yang terdiri atas dua faktor. Faktor pertama adalah konsentrasi propolis $(0.0 \%, 0.5 \%, 1.0 \%, 1.5 \%)$ dan faktor kedua adalah waktu penyimpanan (0 jam, 6 jam, dan 24 jam). Setiap perlakuan dilakukan ulangan sebanyak tiga kali. Daging itik yang dilapisi dengan ekstrak propolis $(0.5 \%, 1.0 \%, 1.5 \%)$ memberikan pengaruh nyata terhadap nilai kadar air dan aktivitas antioksidan daging itik $(\mathbf{P}<\mathbf{0 . 0 5})$. Lama penyimpanan memberikan pengaruh nyata terhadap nilai pH dan susut masak daging itik $(\mathbf{P}<\mathbf{0 . 0 5})$. Penambahan ekstrak propolis dan lama penyimpanan memberikan pengaruh nyata terhadap nilai $\mathrm{pH}$, susut masak dan aktivitas antioksidan daging itik $(\mathrm{P}<0.05)$.

Kata kunci: Daging itik, edible coating, propolis

\section{PENDAHULUAN}

Sumber protein hewani asal unggas di Indonesia masih bertumpu pada ayam pedaging, ayam petelur, dan ayam kampung. Daging itik dapat dijadikan sebagai salah satu sumber protein hewani karena memiliki kandungan protein dan lemak yang hampir sama dengan daging ayam (Matitaputty dan Suryana 2010). Daging itik memiliki sifat yang mudah mengalami kerusakan (perishable food). Kerusakan pada daging itik karena daging tersebut mengandung asam lemak tak jenuh (ALTJ) lebih dari 60\% dari total asam lemak yang menyebabkan daging itik mudah 
mengalami oksidasi selama masa penyimpanan sehingga menurunkan zat gizi dan flavor serta menimbulkan zat yang bersifat toksik (Oteku et al. 2006.). Selain itu kerusakan juga diakibatkan oleh penanganannya kurang baik sehingga memberikan peluang bagi pertumbuhan mikroba pembusuk dan berdampak pada menurunnya kualitas serta daya simpan.

Cemaran dari mikroorganisme dapat diminimalkan dengan pengemasan yang tepat, sehingga dapat mencegah atau memperlambat penurunan kualitas dari suatu produk pangan (Hui 2006). Pengemasan pada daging dapat dilakukan dengan menggunakan pelapis pada bagian permukaan daging,

Senyawa alami yang memiliki potensi sebagai bahan pengemas adalah propolis. Propolis merupakan produk yang dihasilkan oleh lebah madu dari campuran senyawa lilin, enzim $\beta$-glukosidase, dan resin dari bagian tanaman, tunas, dan eksudat yang berasal dari air liur lebah (Rocha et al. 2012). Senyawa bioaktif pada propolis kaya akan flavonoid dan fenoliknya (Segueni et al. 2016). Senyawa tersebut merupakan antioksidan yang dapat digunakan untuk melawan radikal bebas dan dianggap sebagai senyawa fungsional dalam kemasan makanan. Metode edible coating dapat memperpanjang umur simpan dan mempertahankan produk. Edible coating digunakan untuk melapisi bagian permukaan daging sehingga dapat mempertahankan mutu daging dan menjaga produk terhindar dari kontaminasi. Edible coating berfungsi sebagai alternatif teknologi baru untuk meningkatkan umur simpan produk makanan (Kenawi et al. 2011). Salah satu fungsi terpenting dari edible coating yaitu sebagai agen antibakteri. Zat antibakteri mengurangi perkembangbiakan organisme pembusuk selama penyimpanan yang membuat daya simpan daging lebih lama (Lestari et al. 2019).

Salah satu bahan yang sering digunakan sebagai edible coating yaitu kitosan. Kitosan sebagai bahan edible coating merupakan barrier yang baik terhadap gas namun tergolong polisakarida yang kurang baik dalam menghambat uap air (Bourtoom 2008). Suatu bahan pelapis harus memiliki sifat yang dapat menahan air sehingga dapat mencegah hilangnya kelembaban produk, memiliki permeabilitas selektif terhadap gas tertentu (Trisnawaty et al. 2013). Menurut Herawan dan Mahatmanti (2015) propolis merupakan komponen lipid bersifat hidrofobik mampu memberikan kontribusi dalam menahan uap air. Penelitian ini diharapkan dapat menghasilkan informasi yang bermanfaat sebagai acuan pengembangan propolis sebagai alternatif edible coating alami.

\section{MATERI DAN METODE}

\section{Materi}

Penelitian ini menggunakan ekstrak propolis komersial non alkolhol (merek Djoss). Daging itik yang digunakan dalam penelitian ini adalah daging itik bagian dada $50 \mathrm{~g}$ per sampel ketebalan 0.5-1.0 cm dengan berat rataan itik hidup $2.1 \mathrm{~kg}$ per ekor. Sampel daging diperoleh dari rumah potong unggas (RPU) Lapak Unggas, sehingga dapat dengan mudah pemantauan sampel yang diuji.

\section{Metode}

\section{Pembuatan Larutan Propolis Coating}

Metode yang digunakan untuk membuat larutan propolis coating adalah metode Andre et al. (2021) yang dimodifikasi. Pembuatan larutan coating dilakukan dengan melarutkan ekstrak propolis ke pelarut propilen glikol dengan berbagai konsentrasi. Ekstrak propolis sebanyak $1.25 \mathrm{~mL}$ dilarutkan dalam $250 \mathrm{~mL}$ propilen glikol sebagai larutan propolis $0.5 \%(\mathrm{v} / \mathrm{v})$, ekstrak propolis sebanyak 2.5 $\mathrm{mL}$ dilarutan dalam $250 \mathrm{~mL}$ propilen glikol sebagai larutan propolis $1.0 \%(\mathrm{v} / \mathrm{v})$, dan ekstrak propolis sebanyak 3.75 $\mathrm{mL}$ dilarutan dalam $250 \mathrm{~mL}$ propilen glikol sebagai larutan propolis $1.5 \%(\mathrm{v} / \mathrm{v})$.

\section{Perlakuan dan Penyimpanan Sampel}

Metode yang digunakan untuk perlakuan dan penyimpanan sampel adalah metode Andre et al. (2021) yang dimodifikasi. Edible coating propolis dilakukan dengan rancangan faktorial dua perlakukan, faktor pertama adalah konsentrasi propolis $(0.0 \%, 0.5 \%, 1.0 \%, 1.5 \%)$ dan faktor kedua adalah waktu penyimpanan ( 0 jam, 6 jam, dan 24 jam). Setiap perlakuan dilakukan ulangan sebanyak tiga kali. Tiga taraf penambahan konsentrasi ekstrak propolis tersebut $0.5 \%$, $1.0 \%$, dan $1.5 \%$. Persentase ini mengacu kepada penelitian sebelumnya oleh Arumsari (2017). Sampel dipotong dengan ketebalan 1-2 cm dan bobot $\pm 30 \mathrm{~g}$ (Rahardyani 2011). Metode pencelupan (dipping) merupakan metode yang paling banyak digunakan terutama pada produk pangan, dimana produk dicelupkan ke dalam larutan yang digunakan sebagai bahan coating. Sampel di coating selama tiga menit dan dikering anginkan selama \pm 15 menit. Waktu perendaman tiga menit merupakan waktu yang optimal untuk perendaman karena tidak merusak tekstur, bau dan penampakan (Kurnianingrum 2008). Sampel disimpan dalam lemari pada suhu ruang dengan tiga taraf perlakuan waktu yaitu 0 jam, 6 jam, dan 24 jam sebelum di analisis. Taraf perlakuan waktu 6 jam dipilih karena pada waktu tersebut daging berada pada fase rigormortis. Taraf perlakuan waktu 24 jam dipih karena menurut penelitian Fahrurozi (2011) terjadi penurunan kualitas daging pada waktu penyimpanan 24 jam.

\section{Analisis Nilai pH}

Nilai $\mathrm{pH}$ ditentukan dengan menggunakan $\mathrm{pH}$ meter daging merk BOQU PH5S. Alat $\mathrm{pH}$ meter dikalibrasi terlebih dahulu dengan menggunakan buffer $\mathrm{pH} 4$ dan 7. Pengukuran sampel dengan cara menusukkan elektroda ke dalam sampel daging sampai diperoleh pembacaan yang stabil. Nilai $\mathrm{pH}$ daging tertera secara digital di layar $\mathrm{pH}$ meter dan hasil dapat dicatat.

\section{Analisis Kadar Air}

Analisis kadar air dilakukan dengan menggunakan metode oven (AOAC 2005). Prinsipnya dengan menguapkan molekul air bebas yang ada dalam sampel. Sampel ditimbang sampai didapat bobot konstan dengan asumsi semua air yang terkandung dalam sampel sudah diuapkan. Banyaknya air yang diuapkan merupakan selisih bobot sebelum dan sesudah pengeringan. Cawan yang akan digunakan dioven terlebih dahulu selama 30 menit pada suhu $100-105{ }^{\circ} \mathrm{C}$. Cawan didinginkan dalam desikator untuk menghilangkan uap air 
dan ditimbang (A). Sampel ditimbang sebanyak $3 \mathrm{~g}$ dalam cawan yang sudah dikeringkan (B) kemudian dioven pada suhu 100 - $105^{\circ} \mathrm{C}$ selama 5 jam. Sampel didinginkan dalam desikator selama 30 menit dan ditimbang (C).

\section{Analisis Susut Masak}

Perhitungan berat yang hilang selama pemasakan atau pemanasan yang biasa disebut dengan cooking loss (susut masak) dilakukan menggunakan metode Soeparno (2005) yang dimodifikasi. Persiapan sampel diambil seberat $10 \mathrm{~g}$ lalu direbus dengan plastik polietilen pada temperatur $80^{\circ} \mathrm{C}$ selama 60 menit. Setelah perebusan 60 menit, daging diambil dari plastik dan dipisahkan dari air kaldu yang ada. Menyerap air yang ada pada pada permukaan daging dengan tissu tanpa tekanan kemudian ditimbang kembali.

\section{Analisis Malondialdehida (MDA)}

Metode dilakukan berdasarkan kemampuan dalam pembentukan komplek berwarna merah jambu antara MDA (Malondialdehida) dan TBA (asam tiobarbiturat) (RiceEvans dan Antony 1991). Persiapan sampel daging ditimbang sebanyak $1.25 \mathrm{~g}$ per sampel dan disimpan di freezer sebelum dilakukan analisis. Daging coating dari penyimpanan kemudian terlebih dahulu di thawing dan dihancuran sebelum dianalisis di suhu ruang. Sampel yang dicacah kemudian ditambahkan $2.5 \mathrm{~mL}$ buffer phosphat saline $\mathrm{pH} 7.4$ (disimpan pada suhu $5^{\circ} \mathrm{C}$ ). Campuran tersebut kemudian disentrifugasi dengan kecepatan 4000 rpm selama 10 menit. Sebanyak $1 \mathrm{~mL}$ supernatan jernih diambil dan ditambahkan $4 \mathrm{~mL}$ campuran larutan asam klorida $(\mathrm{HCl}) 0.25 \mathrm{~N}$ yang mengandung $15 \%$ asam trikloroasetat $\left(\mathrm{W} \mathrm{v}^{-1}\right), 0.38 \%$ asam tiobarbiturat $\left(\mathrm{w} \mathrm{v}^{-1}\right)$, dan $0.5 \%$ butirat hidroksitoluen $\left(\mathrm{w} \mathrm{V}^{-1}\right)$. Campuran asam klorida dan supernatan tersebut dipanaskan $80^{\circ} \mathrm{C}$ (inkubator) selama 1 jam, selanjutnya didinginkan dengan air mengalir dan disentrifugasi kecepatan 10.000 rpm selama 15 menit. Supernatan hasil sentrifugasi tersebut diukur absorbansinya pada panjang gelombang $532 \mathrm{~nm}$ dengan menggunakan alat spektrofotometer Uv-Vis

\section{Pengujian Antioksidan}

Analisis antioksidan menggunakan metode Tangkanakul et al. (2009) yang dimodifikasi. Aktifitas antioksidan terhadap penghambatan radikal bebas 2.2-Diphenyl-1-picrylhydrazyl (DPPH) dilakukan dengan mereaksikan $0.3 \mathrm{~mL}$ ekstrak metanol daging coating dengan larutan DPPH $0.1 \mathrm{mM}$ (pelarut metanol) sebanyak $1.8 \mathrm{~mL}$ pada tabung vial. Larutan diinkubasi di waterbath suhu $37{ }^{\circ} \mathrm{C}$ selama 30 menit lalu diukur absorbansinya dengan spektrofotometer pada panjang gelombang $517 \mathrm{~nm}$ dengan menggunakan spektrofotometer Uv-Vis. Kapasitas antioksidan diperoleh dengan mengkonversikan nilai \% SA berdasarkan kurva standar. Kurva standar diperoleh dengan pengukuran absorbansi hasil reaksi asam askorbat (konsentrasi $0,0.5,1.0,1.5,2.0$, dan $2.5 \mathrm{mg} 100 \mathrm{~mL}-1$ akuades) dengan DPPH (spektrofotometer. $\lambda=517 \mathrm{~nm}$ ). Kapasitas antioksidan dinyatakan sebagai mg ekuivalen vitamin C $100 \mathrm{~g}^{-1}$ daging coating.

\section{Analisis Statistik}

Penelitian menggunakan metode Rancangan Acak Lengkap (RAL) pola faktorial yang terdiri atas dua faktor. Faktor pertama adalah faktor perlakuan taraf penambahan ekstrak propolis $(0.0 \%, 0.5 \%, 1.0 \%$, dan $1.5 \%)$. Faktor kedua adalah taraf waktu penyimpanan (0 jam, 6 jam, dan 24 jam. Data yang diperoleh dianalisis ragam (analysis of variance, Anova) dengan uji Tukey sebagai uji lanjut (Steel dan Torrie 1993).

\section{HASIL DAN PEMBAHASAN}

\section{Nilai pH}

Hasil analisis ragam menunjukkan bahwa lama penyimpanan dan interaksi antara konsentrasi propolis dan lama penyimpanan menunjukkan pengaruh nyata $(\mathrm{P}<0.05)$ terhadap nilai $\mathrm{pH}$ daging itik. Nilai $\mathrm{pH}$ daging itik yang dilapisi ekstrak propolis selama 24 jam memiliki $\mathrm{pH}$ rentang nilai antara $5.77-6.15$ (Tabel 1). Hasil tersebut masih berada dalam kisaran $\mathrm{pH}$ normal daging yaitu kisaran antara 5.10 6.10 (Edward et al. 1978). Hasil ini juga tidak jauh berbeda dengan penelitian lain yang dilakukan oleh Huda et al. (2011) yaitu $\mathrm{pH}$ daging itik berkisar antara 5.93 - 6.01. Daging itik yang tidak dilapisi ekstrak propolis secara signifikan mengalami peningkatan nilai $\mathrm{pH}$ menjadi $6.50 \pm 0.20$ pada lama penyimpanan 24 jam, sedangkan nilai $\mathrm{pH}$ daging itik yang dilapisi ekstrak propolis tidak mengalami perubahan signifikan terhadap nilai pH selama penyimpanan 24 jam. Perubahan nilai $\mathrm{pH}$ menjadi lebih basa pada daging itik tanpa coating dikarenakan sudah adanya sejumlah bakteri pembusuk melakukan proses fermentasi dan menghasilkan amonia (Dengen 2015).

\section{Kadar Air}

Hasil analisis ragam menunjukkan bahwa pelapisan ekstrak propolis pada daging itik memberikan pengaruh nyata $(\mathrm{P}<0.05)$ terhadap nilai kadar air daging itik (Tabel 2). Nilai kadar air daging itik yang dilapisi ekstrak propolis secara nyata $(\mathrm{P}<0.05)$ lebih rendah dari nilai kadar air daging itik dengan tanpa penambahan konsentrasi ekstrak propolis (kontrol) (Tabel 2). Hasil yang didapatkan sama dengan penelitian Andre et al. (2021) dimana daging yang dilapisi ekstrak propolis cenderung memiliki kadar air rendah. Rendahnya kadar air pada daging itik yang dilapisi

Tabel 1. Nilai pH daging itik

\begin{tabular}{lcccc}
\hline Lama Penyimpanan(jam) & \multicolumn{4}{c}{ Konsentrasi Propolis } \\
\cline { 2 - 5 } & $0,00 \%$ & $0,50 \%$ & $1,00 \%$ & $1,50 \%$ \\
\hline 0 & $5.96 \pm 0.14 \mathrm{bc}$ & $5.89 \pm 0.13 \mathrm{bc}$ & $5.86 \pm 0.10 \mathrm{bc}$ & $5.84 \pm 0.11 \mathrm{bc}$ \\
6 & $5.66 \pm 0.08 \mathrm{c}$ & $5.77 \pm 0.03 \mathrm{bc}$ & $5.87 \pm 0.10 \mathrm{bc}$ & $5.98 \pm 0.10 \mathrm{bc}$ \\
24 & $6.50 \pm 0.20 \mathrm{a}$ & $6.15 \pm 0.19 \mathrm{ab}$ & $6.04 \pm 0.17 \mathrm{bc}$ & $5.81 \pm 0.10 \mathrm{bc}$ \\
\hline
\end{tabular}

Angka yang disertai huruf berbeda pada kolom dan baris yang sama menunjukkan perbedaan yang nyata $(\mathrm{P}<0.05)$. 
Tabel 2. Nilai kadar air daging itik

\begin{tabular}{cccccc}
\hline Lama Penyimpanan (jam) & \multicolumn{2}{c}{ Perlakuan } & \multirow{2}{*}{ Rataan } \\
\cline { 2 - 5 } & $0.00 \%$ & $0.50 \%$ & $1.00 \%$ & $1.50 \%$ & $69.92 \pm 1.02$ \\
\hline 0 & $72.65 \pm 0.67$ & $69.52 \pm 0.70$ & $69.03 \pm 1.40$ & $68.51 \pm 1.29$ & $70.19 \pm 1.20$ \\
6 & $73.01 \pm 0.82$ & $70.02 \pm 1.23$ & $69.67 \pm 0.96$ & $68.06 \pm 1.79$ & $70.17 \pm 1.62$ \\
24 & $74.12 \pm 1.24$ & $69.38 \pm 1.81$ & $68.89 \pm 1.73$ & $68.30 \pm 1.69$ & \\
\hline Rataan & $73.26 \pm 0.91 \mathrm{a}$ & $69.64 \pm 1.25 \mathrm{~b}$ & $69.19 \pm 1.36 \mathrm{~b}$ & $68.29 \pm 1.59 \mathrm{~b}$ & \\
\hline
\end{tabular}

Angka yang disertai huruf berbeda pada kolom dan baris yang sama menunjukkan perbedaan yang nyata $(\mathrm{P}<0.05)$.

ekstrak propolis disebabkan propolis memiliki daya serap air rendah dan bersifat hidrofobik. Kemampuan daya serap air yang rendah ini dapat menekan pengeluaran air hasil dari proses respirasi, sehingga kandungan air dalam daging dapat dipertahankan (Herawan dan Mahatmanti 2015). Rataan nilai kadar air daging itik coating dengan penambahan konsentrasi ekstrak propolis menunjukkan bahwa nilai kadar air berada pada kisaran $68.06 \%$ - 70.02\%, tidak jauh berbeda dengan hasil penelitian Lestari (2018) yang menyatakan kadar air daging itik berkisar 71.13\% - 71.94\% masih berada dalam kisaran kadar air normal daging. Akan tetapi rataan nilai kadar air daging itik tanpa penambahan konsentrasi ekstrak propolis menunjukkan nilai $72.06 \%-74.12 \%$. Kadar air pada daging dapat menentukan kesegaran dan daya simpan daging dimana kadar air yang tinggi dapat menurunkan daya simpan karena mudah terkontaminasi oleh bakteri pembusuk.

\section{Susut Masak}

Susut masak dapat dijadikan salah satu faktor yang menentukan kualitas daging. Susut masak berhubungan dengan air dan zat gizi larut air yang hilang akibat pengaruh pemasakan. Semakin kecil persen susut masak menunjukkan semakin sedikit air dan zat gizi larut air yang hilang dari daging tersebut (Soeparno 2005).

Hasil analisis ragam menunjukkan bahwa lama penyimpanan dan interaksi antara konsentrasi propolis dan lama penyimpanan menunjukkan pengaruh nyata $(\mathrm{P}<0.05)$ terhadap nilai susut masak daging itik (Tabel 3). Pada penyimpanan 0 jam memberikan pengaruh nyata $(\mathrm{P}<0.05)$ terhadap daging itik yang tidak dilapisi ekstrak propolis dimana mendapatkan nilai susut masak $40.05 \pm 0.85$ (Tabel 3). Tingginya nilai susut masak daging itik yang tidak dilapisi ekstrak propolis pada lama penyimpanan 0 jam disebabkan daging mengalami hidrolisis yang menyebabkan struktur daging menjadi lebih longgar atau renggang, sehingga air dalam daging lebih banyak keluar dan membuat nilai susut masak tinggi. Susut masak seringkali dikaitkan dengan penurunan nilai nutrisi daging yang hilang selama proses pemasakan. Soeparno (2009) menyatakan tingginya nilai susut masak akan menurunkan nilai kualitas daging, karena semakin banyak air yang keluar maka jumlah nutrien yang keluar akan lebih banyak.

Nilai susut masak daging itik lama penyimpanan 24 jam lebih rendah dibandingkan dengan lama penyimpanan 0 jam dan 6 jam yang disebabkan proses hidrolisis oleh bakteri pembusuk pada saat penyimpanan di suhu ruang, sehingga kandungan air pada daging berkurang sebelum proses pemasakan. Nilai susut masak pada lama penyimpanan 24 jam juga berkorelasi dengan nilai $\mathrm{pH}$ (Tabel 1) dimana semakin tinggi nilai $\mathrm{pH}$ daging maka persentase susut masak daging akan semakin menurun.

\section{Nilai MDA}

Malondialdehida (MDA) adalah senyawa yang sangat reaktif yang merupakan produk dari peroksidasi lipida dan biasanya digunakan sebagai biomarker peroksidasi lemak untuk menilai stres oksidatif yang bersifat karsinogen (Akdemir dan Sahin 2009). Hasil analisis ragam menunjukkan bahwa penggunaan ekstrak propolis sebagai edible coating pada daging itik, lama penyimpanan serta interaksi keduanya tidak memberikan pengaruh nyata $(\mathrm{P}>0.05)$ terhadap nilai MDA daging itik.

Nilai MDA dipengaruhi oleh banyaknya malondialdehid yang terbentuk pada produk pangan. Nilai MDA daging itik pada penelitian ini memiliki rentang nilai antara $0.28-1.30 \mathrm{mg} \mathrm{kg}^{-1}$ (Tabel 4), hasil ini tidak jauh berbeda dengan hasil penelitian Rukmiasih (2011) yaitu nilai MDA daging itik rata-rata $1.58 \pm 0.26 \mathrm{mg} \mathrm{kg}^{-1}$. Kondisi daging segar yang mengandung kadar MDA $1 \mathrm{mg} \mathrm{kg}^{-1}$ menyebabkan bau tengik berdasarkan panelis terlatih (Vann dan DeWitt 2007).

Pada lama penyimpanan daging itik 24 jam menunjukkan bahwa daging itik coating propolis mendapatkan nilai MDA lebih rendah dibandingkan dengan daging itik tanpa propolis (Tabel 4). Rendahnya nilai MDA disebabkan oleh antioksidan yang terdapat dalam ekstrak propolis berikatan dengan senyawa peroksida yang dihasilkan dari proses oksidasi lemak yang menyebabkan

Tabel 3. Nilai susut masak daging itik

\begin{tabular}{ccccc}
\hline Lama Penyimpanan (jam) & \multicolumn{4}{c}{ Konsentrasi Propolis } \\
\cline { 2 - 5 } & $0.00 \%$ & $0.50 \%$ & $1.00 \%$ & $1.50 \%$ \\
\hline 0 & $40.05 \pm 0.85 \mathrm{a}$ & $36.65 \pm 1.47 \mathrm{bc}$ & $35.16 \pm 1.23 \mathrm{cde}$ & $36.08 \pm 1.20 \mathrm{bcd}$ \\
6 & $38.44 \pm 1.52 \mathrm{ab}$ & $37.54 \pm 1.42 \mathrm{abc}$ & $36.68 \pm 1.50 \mathrm{bc}$ & $37.56 \pm 1.28 \mathrm{abc}$ \\
24 & $29.61 \pm 1.73 \mathrm{~g}$ & $31.65 \pm 1.44 \mathrm{fg}$ & $32.74 \pm 1.34 \mathrm{efg}$ & $33.07 \pm 0.71 \mathrm{def}$ \\
\hline
\end{tabular}

Angka yang disertai huruf berbeda pada kolom dan baris yang sama menunjukkan perbedaan yang nyata $(\mathrm{P}<0.05)$. 
Tabel 4. Nilai MDA daging itik

\begin{tabular}{cccccc}
\hline Lama Penyimpanan (jam) & \multicolumn{4}{c}{ Konsentrasi Propolis } & \multirow{2}{*}{ Rataan } \\
\cline { 2 - 5 } & $0.00 \%$ & $0.50 \%$ & $1.00 \%$ & $1.50 \%$ \\
\hline MDA daging itik mg/kg & $1.11 \pm 0.36$ & $0.64 \pm 0.32$ & $0.76 \pm 0.02$ & $1.20 \pm 0.34$ & $0.93 \pm 0.26$ \\
0 & $0.73 \pm 0.57$ & $0.85 \pm 0.67$ & $0.92 \pm 0.13$ & $0.79 \pm 0.37$ & $0.82 \pm 0.43$ \\
6 & $1.30 \pm 0.93$ & $0.95 \pm 1.19$ & $0.56 \pm 0.42$ & $0.28 \pm 0.15$ & $0.77 \pm 0.67$ \\
24 & $1.05 \pm 0.62$ & $0.81 \pm 0.73$ & $0.75 \pm 0.19$ & $0.76 \pm 0.29$ & \\
\hline Rataan & & & & \\
\hline
\end{tabular}

Angka yang disertai huruf berbeda pada kolom dan baris yang sama menunjukkan perbedaan yang nyata $(\mathrm{P}<0.05)$.

terbentuknya senyawa stabil dan tidak reaktif (Fauziah et al. 2014). Hal tersebut terlihat pada (Tabel 5) bahwa semakin tinggi kapasitas dan aktivitas antioksidan maka semakin kecil MDA. Hal tersebut sesuai dengan Zakaria et al. (2000) antioksidan yang tinggi biasanya diikuti oleh penurunan kadar MDA.

\section{Aktivitas Antioksidan}

Aktivitas antioksidan dalam penelitian ini diidentifikasi melalui aktivitas penghambatan DPPH (1.1-diphenyl-2-picrylhydrazil) dan kapasitas antioksidan. Aktivitas antioksidan dinyatakan dalam persentase penghambatan dan diketahui melalui perbandingan absorbansi sampel dengan absorbansi standar. Sementara itu kapasitas antioksidan menggambarkan jumlah antioksidan berdasarkan kurva kalibrasi penghambatan DPPH oleh asam askorbat. Hasil analisis ragam menunjukkan bahwa penambahan ekstrak propolis sebagai edible coating pada daging itik, lama penyimpanan serta interaksi keduanya memberikan pengaruh nyata $(\mathrm{P}<0.05)$ terhadap nilai penghambatan DPPH dan kapasitas antioksidan.

Berdasarkan uji statistik, rataan nilai aktivitas antioksidan daging itik coating dengan penambahan konsentrasi ekstrak propolis menunjukkan bahwa persentase nilai penghambatan DPPH berada pada kisaran 29.72\% $83.33 \%$ dan nilai kapasitas antioksidan berada pada kisaran 110.90 - $275.58 \mathrm{mg}$ AEAE $100 \mathrm{~g}^{-1}$. Dengan demikian, daging coating yang memiliki kapasitas antioksidan sebesar $275.58 \mathrm{mg}$ AEAC $100 \mathrm{~g}^{-1}$ memiliki arti bahwa setiap 100 g daging coating mampu meredam radikal bebas sebesar $275.58 \mathrm{mg}$ atau setara dengan $83.33 \%$. Aktivitas antioksidan daging itik tanpa penambahan ekstrak propolis lama penyimpanan 0 jam, 6 jam, dan 24 jam tidak memberikan pengaruh nyata $(\mathrm{P}>0.05)$ menunjukkan bahwa persentase nilai penghambatan DPPH berada pada kisaran 15.51\% $16.42 \%$ dan nilai kapasitas antioksidan berada pada kisaran 66.97 - 70.03 mg AEAE $100 \mathrm{~g}^{-1}$.

Kapasitas antioksidan menggambarkan sejumlah antioksidan di dalam daging itik yang dikalibrasi berdasarkan kurva standar penghambatan DPPH oleh asam askorbat. Menurut Tangkanakul (2009) bahwa tingkatan kapasitas antioksidan bahan-bahan dibagi menjadi empat kelompok: sangat tinggi (>500 mg VCE $\left.100 \mathrm{~g}^{-1}\right)$, tinggi (200 - $500 \mathrm{mg}$ VCE $\left.100 \mathrm{~g}^{-1}\right)$, sedang (100 - $200 \mathrm{mg}$ VCE $\left.100 \mathrm{~g}^{-1}\right)$ dan rendah $\left(<100 \mathrm{mg}\right.$ VCE $\left.100 \mathrm{~g}^{-1}\right)$. Kapasitas antioksidan yang tinggi pada daging itik yang dilapisi ekstrak propolis disebabkan propolis memiliki kandungan flavonoid dan fenolik yang berperan besar terhadap aktivitas antioksidan. Kedua senyawa tersebut berperan dalam menangkap elektron bebas hasil oksidasi (Marghitas et al. 2009).

\section{KESIMPULAN}

Daging itik yang dilapisi ekstrak propolis memberikan pengaruh nyata terhadap nilai $\mathrm{pH}$, kadar air, susut masak serta aktivitas antioksidan yang mampu menghambat oksidasi pada daging itik dari ketengikan selama penyimpanan 24 jam di suhu ruang. Perlakuan coating propolis pada konsentrasi $1.5 \%$ lebih efektif menstabilkan nilai $\mathrm{pH}$, mengurangi susut masak, mengurangi angka ketengikan serta memiliki kapasitas antioksidan tertinggi. Ekstrak propolis dalam hal ini berpotensi mampu mempertahankan kualitas daging itik selama penyimpanan 24 jam di suhu ruang

Tabel 5. Aktivitas penghambatan DPPH dan kapasitas antioksidan daging itik

\begin{tabular}{ccccc}
\hline \multirow{2}{*}{$\begin{array}{c}\text { Lama Penyimpanan } \\
(\text { Jam })\end{array}$} & $0.00 \%$ & $0.50 \%$ & $1.00 \%$ & $1.50 \%$ \\
\cline { 2 - 5 } & & \multicolumn{4}{c}{ Aktivitas penghambatan DPPH \% } \\
\hline 0 & $16.42 \pm 8.04 \mathrm{e}$ & $62.76 \pm 20.81 \mathrm{abc}$ & $41.45 \pm 18.38 \mathrm{bcde}$ & $60.93 \pm 20.90 \mathrm{abcd}$ \\
6 & $16.20 \pm 12.52 \mathrm{e}$ & $36.47 \pm 21.19 \mathrm{cde}$ & $29.72 \pm 15.30 \mathrm{de}$ & $71.34 \pm 20.21 \mathrm{ab}$ \\
24 & $15.52 \pm 5.65 \mathrm{e}$ & $60.58 \pm 16.88 \mathrm{abcd}$ & $81.96 \pm 12.41 \mathrm{a}$ & $83.33 \pm 8.09 \mathrm{a}$ \\
\hline & & Kapasitas antioksidan $\left(\mathrm{mg} \mathrm{AEAC} 100 \mathrm{~g} \mathrm{~g}^{-1}\right)$ & $206.78 \pm 64.20 \mathrm{abcd}$ \\
6 & $70.03 \pm 24.69 \mathrm{e}$ & $212.40 \pm 63.92 \mathrm{abc}$ & $146.91 \pm 56.47 \mathrm{bcde}$ & $238.74 \pm 62.08 \mathrm{ab}$ \\
24 & $69.36 \pm 38.48 \mathrm{e}$ & $131.64 \pm 65.09 \mathrm{cde}$ & $110.90 \pm 47.01 \mathrm{de}$ & $275.58 \pm 24.87 \mathrm{a}$ \\
\hline
\end{tabular}

Angka yang disertai huruf berbeda pada kolom dan baris yang sama menunjukkan perbedaan yang nyata $(\mathrm{P}<0.05)$. 


\section{DAFTAR PUSTAKA}

AOAC (Association of Official Analytical Chemyst). 2005. Official Method of Analysis of The Association of Official Analytical of Chemist. Arlington, Virginia (USA): Published by The Association of Official Analytical Chemist. Inc.

Akdemir, F., \& K. Sahin. 2009. Genistein supplementation to the quail: effects on egg production and egg yolk genistein, daidzein, and lipid peroxidation levels. Poult. Sci. 88(10):2125-2131.

Andre, A. Apriantini, \& C. Budiman. 2021. Pengaruh Ekstrak Propolis sebagai Edible Coating terhadap Karakteristik Kimia dan Aktifitas Antioksidan Daging Sapi pada Penyimpanan Suhu Ruang. Jurnal Ilmu Produksi dan Teknologi Hasil Ternak. 9 (2): 72-78.

Arumsari, A. D. 2017. Pengaruh edible coating kitosan dengan penambahan minyak esensial jahe terhadap mutu daging sapi pada suhu ruang [tesis]. Malang: Universitas Brawijaya.

Bourtoom, T. 2008. Review article edible film and coating: characteristics andproperties. International Food Research Journal. 15(3):237-248.

Bourtoom. 2008. Edible film and coating: characteristic and properties. International Food Research Journal. 15(3): $1-13$.

Dengen, P. M. R. 2015. Perbandingan uji pembusukan menggunakan metode uji postma, uji eber, uji H2S dan pengujian mikroorganisme pada daging babi di 17 pasar tradisional sentral makassar [skripsi]. Makassar: Universitas Hasanuddin.

Edward, R. A., G. H. Fleet, \& M. Woottoon. 1978. Foodcommodity science. In: K.A. Buckle, R.A. Edward, G.H. Fleet and M. Wooton (Eds.). Acourse manual in food science. Australian Vicechancellors Committee. Watson Ferguson and Co. Brisbane.

Fahrurozi. 2011. Kualitas sifat fisikokimia daging sapi terhadap lama penyimpanan [skripsi]. Jakarta: Universitas Islam Negeri Syarif Hidayatullah.

Fauziah, N., S. Fronthea, \& R. Laras. Kajian efek antioksidan asap cair terhadap oksidasi lemak ikan pindang layang selama penyimpanan suhu ruang. Jurnal Pengolahan dan Bioteknologi Hasil Perikanan. 3(4):7177.

Herawan, C. D., \& F. W. Mahatmanti. 2015. Sintesis dan karakteristik edible film dari pati kulit pisang dengan penambahan lilin lebah. Indonesian Journal of Chemical Science. 4(2):148-151.

Huda, N. P., \& A. A. R. Ahmad. 2011. Proximat and physicochemical properties of peking and Muscovy duck breasts and thighs for further processing. J Food Agric Environt. 9:82-88.

Hui, Y. H. 2006. Handbook of Food Science. Technology and Engineering Volume 1. Amerika Serikat (USA): CRC Press.

Kenawi, M. A., M. M. A. Zaghlul, \& R. R. Abdel-Salam. 2011. Effect of two natural antioxidants in combination with edible packaging on stability of lowfat beef product storedunder frozen condition. Biotechnology in Animal Husbandry. 27(3):45-356.
Kurnianingrum, V. I. 2008. Efektivitas desinfektan alami dari chitosan sebagai pereduksi bakteri Escherichia coli dan beberapa bakteri lain yang teridentifikasi pada udang galah segar [skripsi]. Bogor: Institut Pertanian Bogor.

Lestari, D. 2018. penurunan bau amis dan kadar malondialdehida daging itik cihateup dengan pemberian daun beluntas dan kenikir [skripsi]. Bogor: Institut Pertanian Bogor.

Lestari, T., B. Setiawan, R. N. Praja, R. Damayanti, R. A. Prastiya, \& P. A. Wibawati. 2019. Pengaruh perendaman daging sapi dalam larutan rimpang kunyit (Curcuma domestica val.) dengan kombinasi konsentrasi dan lama waktu penyimpanan terhadap total jumlah bakteri. Jurnal Medik Veteriner. 2(1):55-59.

Marghitas, L. A., D. Dezmirean, A. Moise, C. M. Mihai, \& L. S. Laslo. 2009. DPPH Method Evaluastion of propolis antioxidant activity. Bultetin UASVM Animal Science and Biotechnology. 66(1-2):253-258.

Matitaputty, P. R., \& Suryana. 2010. Karakteristik daging itik dan permasalahan serta upaya pencegahan off-flavor akibat oksidasi lipida. Wartazoa. 20(3):130-138.

Oteku, I. T., J. O. Igene, \& I. M. Yessuf. 2006. An assessment of the factors influencing the consumption of duck meat in Southern Nigeria. Pakistan J. Nutrition. 5(5):474-477.

Rahardyani. 2011. Efek daya hambat kitosan sebagaai edible coating terhadap mutu daging sapi selama penyimpanan suhu dingin [skripsi]. Bogor: Institut Pertanian Bogor.

Rice, E. C., \& T. D. Anthony. 1991. Techniques in Free Radical Research. Elscvier. Pp 146-202.

Rocha, B. A., M. R. Rodrigues, P. C. P. Bueno, A. R. CostaMachado, A. P. Vaz MM Nascimento, H. S. Barud, \& A. A. Beretta-Silva. 2012. Preparation and thermal characterization of inclusion complex of Brazilian green propolis and hydroxypropyl- $\beta$-cyclodextrin. J Therm Anal Calorim. 108:8-94.

Rocha, B. A., M. R. Rodrigues, P. C. P. Bueno, A. R. Machado, M. M. Vaz, A. P. Nascimento, H. S. Barud, \& A. A. Silva. 2012. Preparation and thermal characterization of inclusion complex of Brazilian green propolis and hydroxypropyl- $\beta$ cyclodextrin. J Therm Anal Calorim. 108:8-94.

Rukmiasih. 2011. Penurunan bau amis (off-odor) daging itik lokal dengan pemberian tepung daun beluntas (pluchea indica 1.) dalam pakan dan dampaknya terhadap performa [skripsi]. Bogor: Institut Pertanian Bogor.

Segueni, N., A. Zellagui, F. Moussaoui, M. Lahouel, \& S. Rhouati. 2016. Flavonoids from Algerian Propolis. Arabian Journal of Chemistry. 425-428.

Soeparno. 2005. Ilmu dan Teknologi Daging. Yogyakarta: UGM Press.

Soeparno. 2009. Ilmu dan Teknologi Daging. Ed ke-5. Yogyakarta: Universitas Gadjah Mada Pr.

Soeparno. 2009. Ilmu dan Teknologi Daging. Yogyakarta: UGM Press.

Steel, R. G. D., \& J. H. Torrie. 1993. Prinsip dan Prosedur Statistika Suatu Pendekatan Biometrik. Jakarta: PT. Gramedia Pustaka Utama.

Tangkanakul, P., P. Auttaviboonkul, B. Niyomwit, N. Lowvitoon, P. Charoenthamawat, \& G. Trakoontivakorn. 2009. Antioxidant capacity, total 
phenolic content and nutritional composition of Asian foods after thermal processing. IFRJ. 16:571-580.

Trisnawati, E. D. Andesti, \& A. Saleh. 2013. Pembuatan kitosan dari limbah cangkang kepiting sebagai bahan pengawet buah duku dengan variasi lama pengawetan. Jurnal Teknik Kimia. 19(2): 19-26.
USDA (United States Department of Agriculture). 2007. USDA National Nutrient Database for Standard Reference. Washington (USA): Published by The United States Department of Agriculture.

Zakaria, F. R., D. N. Sandjaja, \& S. M. Pramudya. 2000. Hubungan antara status imunologi dan pola konsumsi makanan jajanan populasi remaja di Bogor Jawa Barat. J Teknol dan Indust Pangan. 1(2):50-59. 